YEARBOOK

of ANTITRUST

and REGULATORY

STUDIES

www.yars.wz.uw.edu.pl
Peer-reviewed scientific periodical, focusing on legal and economic issues of antitrust and regulation.

Creative Commons Attribution-No Derivative Works 3.0 Poland License.

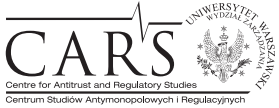

Centre for Antitrust and Regulatory Studies, University of Warsaw, Faculty of Management www.cars.wZ.uw.edu.pl

\title{
How to Throw the Baby out with the Bath Water. A Few Remarks on the Currently Accepted Scope of Civil Liability for Antitrust Damages
}

\author{
by
}

Agata Jurkowska-Gomułka*

\section{CONTENTS}

I. Introduction

II. Personal dimension of civil antitrust liability

1. Culpability

2. Joint and several liability

3. Immunity recipients in leniency

4. Settling co-infringers

III. Subject-matter dimension of antitrust liability

1. General rules for the scope of damages

2. Passing-on of overcharges

3. Umbrella pricing

VI. Final remarks

\section{Abstract}

The Damages Directive introduces the right to 'full compensation' and the principle of 'joint and several liability' for antitrust damages (Article 3(1) and Article 11(1) respectively). The Directive does not determine the type of damage that can be awarded in civil proceedings. In theory, there are thus no barriers to establish punitive, multiple or other damages. In practice, it is rather unlikely that such types of damages will be awarded after the implementation of the Directive due to the ban placed on overcompensation in its Article 2(3).

* Prof. Agata Jurkowska-Gomułka, Chair of Administrative Law, University of Information Technology and Management in Rzeszow (Poland); Of-Counsel Modzelewska\&Paśnik, Warsaw; e-mail: agathajur@o2.pl. 
This paper will try to decode the concept of 'full compensation' and 'joint and several liability' in light of the Damages Directive as well as EU jurisprudence. An adequate understanding of these terms is without a doubt one of the key preconditions of correctly implementing the Directive and, consequently, a condition for making EU (competition) law effective.

While on the one hand, a limitation of the personal scope of civil liability can currently be observed in EU law (covering both legislation and case law), a broadening of its subject-matter scope is visible on the other hand. With reference to the personal scope of civil liability, the Directive itself limits the applicability of the joint and several responsibility principle towards certain categories of infringers: small \& medium enterprises (Article 11(2)) and immunity recipients in leniency (Article 11(3)). Considering the subject-matter scope of civil liability, the acceptance by the Court of Justice of civil liability for the 'price umbrella effect' should be highlighted. In addition, the principle of the 'passing-on defence' can also be regarded as a manner of broadening the scope of civil liability for antitrust damage (Article 12-16).

The paper will present an overview of the scope of civil liability for antitrust damages (in its personal and subject-matter dimension) in light of the Directive and EU jurisprudence. The paper's goal is to assess if the applicable scope will in fact guarantee the effective development of private competition law enforcement in EU Member States. This assessment, as the very title of this paper suggests, will be partially critical.

\section{Résumé}

La Directive relative aux actions en dommages introduit le droit de la «réparation intégrale» et le principe de la «responsabilité solidaire» dans le context des préjudices causés par des pratiques anticoncurrentielles (l'article 3(1) et l'article 11 (1), respectivement). La Directive ne précise pas le type de dommage qui peut être accordée dans les procédures civiles. En théorie, il n'y a donc pas d'obstacles pour accorder des dommages punitifs, multiples ou d'autres. Néanmoins, en pratique, il est peu probable que les dommages de ce type seront accordés après la mise en ouvre de la Directive, en raison de l'interdiction de la réparation excessive introduit dans l'article 2 (3) de la Directive.

Cet article va tenter d'interpréter la notion de la «réparation intégrale» et la «responsabilité solidaire» à la lumière de la Directive, ainsi que la jurisprudence de cours européennes. Une bonne compréhension de ces termes est sans doute l'une des conditions essentielles de la mise en œuvre correct de la Directive et, par conséquent, la condition d'efficacité du droit européen de la concurrence.

D'une part, nous pouvons actuellement observer la limitation du champ d'application personnel de la responsabilité civile dans le droit européen (dans la législation européenne et dans la jurisprudence), mais d'autre part, nous pouvons aussi remarquer un élargissement du champ d'application matérielle. En faisant la 
référence au champ d'application personnel de la responsabilité civile, la Directive limite l'application du principe de la responsabilité solidaire à l'égard de certaines catégories de contrevenants : des petites et moyennes entreprises (l'article 11 (2)) et des bénéficiaires d'une immunité accordée dans le programme de clémence (l'article 11 (3)). En ce qui concerne le champ d'application matérielle, nous devons souligner l'acceptation par la Cour de justice de l'Union européenne le principe de la responsabilité civile pour «l'effet parapluie». De plus, le principe de la répercussion du surcoût peut aussi être considéré comme une manière d'élargissement du champ d'application de la responsabilité civile pour les préjudices causés par des pratiques anticoncurrentielles (les articles 12-16).

Cet article va présenter une vue d'ensemble des règles concernant la responsabilité civile pour les préjudices causés par des pratiques anticoncurrentielles (dans sa dimension personnelle et matérielle) à la lumière de la Directive et la jurisprudence européenne. Son objectif est d'évaluer si le champ d'application actuelle pourrait garantir le développement efficace de l'application privée du droit de la concurrence privée dans les États membres de l'UE. Cette évaluation, comme le titre même de cet article l'indique, sera partiellement critique.

Key words: antitrust civil liability; damage; Directive 12014/104; joint and several liability; immunity recipient; private enforcement of competition law; public enforcement of competition law; umbrella pricing.

JEL: K23; K42.

\section{Introduction}

After a long-lasting debate on harmonizing the rules on private enforcement of competition law in the EU, a Directive on certain rules governing actions for damages under national law for infringements of the competition law provisions of the Member States and of the European Union was ultimately born ${ }^{1}$ in November 2014 (hereafter, Damages Directive or Directive). The Directive provides a framework of solutions, some of which are of a very general character. As a result, they must be 'completed' by much more detailed provisions of national laws. It is a commonly recognized opinion that implementing the Damages Directive will be quite challenging for Member States. A key reason for this realisation lies in the fact that some of the rules of the Directive nearly devastate traditional institutions (or their traditional interpretation) of

1 Directive 2014/104/EU of the European Parliament and of the Council of 26 November 2014 on certain rules governing actions for damages under national law for infringements of the competition law provisions of the Member States and of the European Union (OJ L 349, 05.12.2014, p. 1) (hereafter, Damages Directive). 
civil law, especially in countries with legal systems shaped as statutory law. Another reason making the implementation process rather difficult lies in the jurisprudence of the Court of Justice of the EU (hereafter, CJ) that can surely not be ignored by national lawmakers. In fact, it is not only the Damages Directive itself, but also EU jurisprudence that must be 'implemented' in prospective national regulations on private antitrust enforcement. On the one hand, judgments of the $\mathrm{CJ}$ may be helpful in shaping provisions at the national level because they provide details than the Directive lacks. Yet on the other hand, some rulings, such as Kone ${ }^{2}$, offer solutions that can be considered rather controversial from the point of view of national civil law.

This paper aims to analyze two aspects of antitrust liability: its personal and subject-matter scope. An analysis on how these two aspects have been shaped in EU legislation and jurisprudence lead to a simple conclusion harmonisation went partially in the wrong direction. Rather than strengthen the effectiveness of antitrust law and its private enforcement, the guidelines provided by the EU lawmaker and judiciary somehow limited the benefits resulting from private antitrust enforcement and upset the sensitive balance between both (public and private) enforcement methods of Articles 101 and 102 TFEU and corresponding national provisions.

\section{Personal dimension of civil antitrust liability}

\section{Culpability}

Prohibitions of competition restricting practices can be regarded as totally free from the concept of culpability, which in fact means that 'guilt' does not constitute a prerequisite for applying the prohibitions. Another idea considers the antitrust bans as being dependent on the concept of 'fault', although both voluntary and involuntary (unintentional) activity causes responsibility for antitrust breaches within public enforcement of competition law. Regardless of the theoretical basis, approving either idea means that while applying the prohibitions (be it the ban on cartels or on the abuse of dominance) there is no need to prove if an infringer is guilty or not. 'Fault', as a factor reflecting the degree of involvement in, and awareness of, the anticompetitive behaviour, can be taken into account when calculating the amount of the fine to be imposed. However, one of a most appealing example of 'ignoring' the concept

\footnotetext{
2 Case C-557/12 Kone AG and Others v. ÖBB-Infrastruktur AG, ECLI:EU:C:2014:1317.
} 
of culpability while determining antitrust liability in the public enforcement domain is the application of the single economic unit doctrine.

However, 'fault' cannot be treated as non-existent in private enforcement of competition law, like it usually is in public enforcement, mainly because 'fault' constitutes a necessary condition of civil liability in certain cases, especially liability for torts. Accepting culpability, as one of the necessary conditions for antitrust liability, would simultaneously determine which legal basis for civil liability is acceptable in private antitrust enforcement. As the CJ claimed in the recent $C D C$ case: '[...] since the requirements for holding those participating in an unlawful cartel liable in tort may differ between the various national laws, there would be a risk of irreconcilable judgments if actions were brought before the courts of various Member States by a party allegedly adversely affected by a cartel $[\ldots]^{3}$. For example, tort liability in the Polish Civil Code is based on the concept of culpability. Hence, making Article 415 of the Civil Code (establishing rules of tort liability) the legal basis for claims in antitrust cases requires proving 'fault'4. In fact, accepting culpability as a prerequisite of antitrust liability should also be considered a method of determining the circle of potential defendants in private antitrust enforcement cases.

Yet the EU did not take this opportunity. The Damages Directive itself does not point to culpability as the basis for antitrust liability - Member States are (theoretically) free in their choice in this regard. This may result in a differentiation of the scope of entities held liable before civil courts for anticompetitive practices in various Member States. Having said that, the freedom that Member States have in making culpability the basis for antitrust liability is limited by the principle of effectiveness and, although to a smaller degree, by the principle of equivalence. This realisation can be traced back to Recital 11 of the Directive's Preamble: 'Where Member States provide other conditions for compensation under national law, such as imputability, adequacy or culpability, they should be able to maintain such conditions in so far as they comply with the case-law of the Court of Justice, the principles of effectiveness and equivalence, and this Directive'.

Importantly, EU jurisprudence draws a rather wide circle of entities to which a violation of Article 101 and 102 TFEU can be attributed to ${ }^{5}$. Hence, the

3 C-352/13 Cartel Damage Claims (CDC) Hydrogen Peroxide SA v. Akzo Nobel NV, Solvay NV, Kemira Oyj, FMC Foret SA, ECLI:EU:C:2015:335, para. 22.

${ }^{4}$ Possible legal basis for antitrust legal liability are thoroughly analyzed by: A. Jurkowska, 'Antitrust Private Enforcement - Case of Poland' (2008) 1(1) YARS 64-67; P. Podrecki, 'Civil Law Actions in the Context of Competition Restricting Practices under Polish Law' (2009) 2(2) YARS 78-98; R. Stefanicki, Prywatnoprawne środki dochodzenia roszczeń z tytutu naruszenia regut konkurencji, Warsaw 2014, p. 215-245.

5 I.e. cases of undertakings who are not direct members of a cartel but who act as 'facilitators' for the cartelists and are held responsible for infringing Art. 101 TFEU - see Commission's 
independence of Member States to determine - at least from the perspective of culpability - the personal scope of antitrust civil liability is rather illusionary, provided they want to comply with the principle of effectiveness of EU law, directly stated in Article 4 of the Damages Directive.

\section{Joint and several liability}

Surprisingly, it was the EU lawmaker itself which introduced into the Damages Directive a provision that seriously violates the effectiveness of EU competition law. Article 11(2) establishes a derogation from the principle of joint and several liability expressed directly, as the basic rule for antitrust civil liability, in Article 11(1). Under two cumulative conditions, small and medium sized enterprises (hereafter, SMEs) are exempted from joint and several liability - instead, they are liable only to their own direct and indirect purchasers. A SME is entitled to benefit from this derogation if 'its market share in the relevant market was below $5 \%$ at any time during the infringement of competition law' (Article 11(2)(a)) and 'if the application of the normal rules of joint and several liability would irretrievably jeopardise its economic viability and cause its assets to lose all their value' (Article 11(2)(b)).

It is assumed here that the principle of joint and several liability for antitrust infringements is fair and suitable for antitrust cases. Hence, the derogation provided in Article 11(2) has to be firmly and expressly disagreed with. First, it totally spoils the 'democratic' character of antitrust prohibitions expressed in Article 101 and 102 TFEU (and corresponding domestic provisions). These prohibitions are normally applied regardless of the status or size of the undertakings concerned or their financial performance. Even in calculating fines by the Commission (as well as, for example, Poland's National Competition Authority - the UOKiK President), the size of an enterprise does not matter! The exemption provided by Article 11(2) of the Directive may thus be seen as undermining the deterrence effect of potential damages actions towards $\mathrm{SMEs}^{6}$.

An infringer's inability to pay is an issue that can have an impact on the level of the fine imposed in public enforcement proceedings. According

decision of 11 November 2011 (COMP/38.589) and related case T-27/10 AC-Treuhand AG v. Commission, ECLI:EU:T:2014:59 (appeal case C-194/14 P before the Court of Justice still pending).

6 S. Peyer, 'Antitrust Damages Directive - much ado about nothing?' [in:] M. Marquis, R. Cisotta (eds.), Litigation and arbitration in EU competition law, Edward Elgar Publishing 2015, p. 41. See also a critical view of a derogation for SMEs presented by S.O. Pais, A. Piszcz, 'Package on Actions for Damages Based on Breaches of EU Competition Rules: Can One Size Fit All?' (2014) 7(10) YARS 226-228. 
to paragraph 35 of the Guidelines on the method of setting fines imposed pursuant to Article 23(2)(a) of Regulation No. 1/20037, the Commission may grant a fine reduction to an undertaking 'solely on the basis of objective evidence that imposition of the fine as provided for in these Guidelines would irretrievably jeopardise the economic viability of the undertaking concerned and cause its assets to lose all their value'.

In truth, the wording of the abovementioned paragraph of the Guidelines and the wording of Article 11(2)(b) of the Damages Directive are identical. Some might claim therefore that the solution applied in the Directive is somehow justified. This view cannot be supported however: even if the condition for inability to pay is formulated in the same manner as the SME derogation, the objective and context of its application are slightly different. When the Commission considers the condition of inability to pay, the total fine for the given antitrust practice is decreased - this is a sort of 'amnesty' for the infringer. In the context of private antitrust enforcement, the prerequisite of inability to pay is not an instrument for modifying the level of damages (which can be considered a 'fine' in civil law). Instead, it is an instrument for modifying the way in which damages are distributed. The EU lawmaker seems to have forgotten that joint and several liability does not actually mean that only certain defendants, instead of all of them, fulfil their obligations towards plaintiffs. Joint and several liability gives plaintiffs easier access to damages. It does not exclude the possibility of recovering a relative part of damages paid to plaintiffs from 'co-infringers' (defendants) - this is what recourse claims are for!

In line with how the derogation guaranteed in Article 11(2) is understood here, it is regarded as a shield against an excessive number of claims being addressed towards an SME in difficulties, which could cause a further deterioration of that company's financial condition. But why are only SMEs protected against such risk? Large enterprises can face the same difficulties in fact, this is even more likely than for SMEs because large infringers usually generate a far greater number of antitrust 'victims' than SMEs (a simple result of differences in their client numbers).

The above derogation from the principle of joint and several liability was introduced into the Damages Directive by the European Parliament ${ }^{8}$. It seems

7 Guidelines on the method of setting fines imposed pursuant to Article 23(2)(a) of Regulation No. 1/2003 (OJ C 210, 01.09.2006, p. 1).

8 See Draft European Parliament Resolution on the proposal for a directive of the European Parliament and of the Council on certain rules governing actions for damages under national law for infringements of the competition law provisions of the Member States and of the European Union (COM(2013)0404 - C7-0170/2013 - 2013/0185(COD)), available at: http://www.europarl.europa.eu/sides/getDoc.do?pubRef=-//EP//TEXT+REPORT+A7-2014$0089+0+\mathrm{DOC}+\mathrm{XML}+\mathrm{V} 0 / / \mathrm{EN}$ (access 5.10.2015). 
that the Parliament still promotes the 'SME approach' despite the fact that the latter is currently being contested by many economists because the strength of SMEs as an economic driving force seems to have been overestimated ${ }^{9}$. In fact, a total collapse of a large company, that occurred for example as a result of fulfilling joint and several liability for antitrust torts, may have much more serious economic and social consequences than the collapse of a SMEs.

As a matter of fact, Article 11(2) of the Directive makes the enforcement of antitrust rules before national courts more difficult (at least in cases concerning SMEs fulfilling the conditions prescribed in this provision). Due to the European Parliament, it is mainly private entities (excluding situations when public authorities submit antitrust claims as the Commission did in the Otis case ${ }^{10}$ ) that must bear the burdens of public policy goals in this context. Thankfully at least, the Parliament stopped its intervention at Article 11(2) and did not 'improve' the Directive any further with yet another pro-SMEs rule, this time on the possibility of a court decreasing the amount of damages that SMEs are obliged to pay as their relative part of liability. It is surprising that the Preamble to the Directive does not say a word about the derogation introduced in Article 11(2).

Instead of making certain categories of enterprises somehow privileged in private antitrust enforcement, it is fair to say that the EU lawmaker should have had more trust in national legal systems and in national judiciaries - the institution of joint and several liability is well settled both in law and practice, and used in many economic and social contexts.

\section{Immunity recipients in leniency}

The principle of joint and several liability is also limited with respect to undertakings that successfully applied for leniency and gained total immunity from fines (hereafter, immunity recipient). According to Article 11(4) of the Damages Directive, an immunity recipient is generally liable jointly and severely only towards its direct or indirect purchasers or providers. However,

9 See e.g. D. Hirschberg, The Job-Generation Controversy: The Economic Myth of Small Business, Routledge 2015; R. K. Gruenwald, 'Alternative Approaches in Evaluating the EU SME Policy: Answers to the Question of Impact and Legitimization' (2014) 2(2) Entrepreneurial Business and Economics Review 77-88; R. Levine, 'Should government and aid agencies subsidize small firms' [in:] L. Brainard (ed.), Transforming the Development Landscape: The Role of the Private Sector, Washington 2006, p. 66 et seq.; R. Parker, 'The Myth of the Entrepreneurial Economy' (2001) 15(2) Work, Employment and Society; S.J. Davis, J. Haltiwanger, S. Schuh, 'Small Business and Job Creation: Dissecting the Myth and Reassessing the Facts' (1993) 8(4) Small Business Economics 297-315.

${ }^{10}$ Case C-199/11 Europese Gemeenschap v. Otis NV and Others, ECLI:EU:C:2012:684. 
joint and severe liability of an immunity recipient towards other injured parties is 'restored' 'where full compensation cannot be obtained from the other undertakings that were involved in the same infringement of competition law'. It is worth noting that the scope of the derogation for immunity recipients guaranteed in Article 11(4) is more modest than that offered to SMEs in Article 11(2). Still, the Directive provides some other reservations for executing antitrust civil liability of immunity recipients. First, according to Article 11(5), when a group of liable infringers makes a claim to recover a contribution from other liable infringers, the amount of the contribution of an immunity recipient 'shall not exceed the amount of the harm it caused to its own direct or indirect purchasers or providers'. Second, in the case of liability for harms caused to entities who are not direct or indirect purchasers or providers, according to Article 11(6) 'the amount of any contribution from an immunity recipient to other infringers shall be determined in the light of its relative responsibility for that harm'.

Leniency is one of the key tools of a successful and effective fight against cartels. Failure to provide any sort of protection for leniency applicants for private antitrust enforcement would certainly make this tool ineffective or even non-existent. The reasons behind giving special treatment to immunity recipients are explicitly listed in Recital 38 of the Directive's Preamble. First, whistle-blowers deserve such protection because they contribute to bringing an infringement to an end, a fact that translates into a limitation of the scope of the resulting harm. Second, '(...) the decision of the competition authority finding the infringement may become final for the immunity recipient before it becomes final for other undertakings which have not received immunity, thus potentially making the immunity recipient the preferential target of litigation'.

Certainly, a derogation from the principle of joint and several liability for immunity recipients exemplifies a situation when private antitrust enforcement takes a backseat, giving priority to public enforcement. While supporting a rational, well-balanced and sustainable co-existence of both enforcement methods, the solution adopted in the Damages Directive must be fully approved of. The fact should be appreciated in particular that the derogation did not go too far and its application is limited to immunity recipients only.

\section{Settling co-infringers}

The Damages Directive contains one more limitation of the principle of joint and several liability - Article 19 sets out special rules for awarding damages in the case of a settlement. According to Article 19(1), as a result of a settlement, the claim of a settling injured party is reduced by the settling 
co-infringer's share of the harm that the antitrust infringement inflicted upon the injured party. The rest of the claim can be executed only against non-settling co-infringers, non-settling co-infringers are not allowed to get a contribution for the remaining claim from the settling co-infringer (Article 19(2)). Damages be successfully demanded in full from a settling infringer only if non-settling co-infringers are unable to pay, unless that possibility is directly excluded in the text of the settlement (Article 19(3)).

It is not easy to find any good reasons for adopting an exception from the standard rule of civil antitrust liability guaranteed by the Directive for settling antitrust infringers. Recital 51 of the Directive's Preamble is not convincing, which treats leniency programmes and settlements in the same manner, as if they served the same objectives. Leniency help discover prohibited practices - it can be safely assumed that some claimants would not even know about an antitrust infringement if not for leniency. Hence, the use of leniency within public enforcement can benefit not only the leniency applicants themselves, but also (potential) claimants. By contrast, settlements are beneficial mainly to competition authorities. The fact that antitrust proceedings come to an end faster, and that a potential claimant can sue the infringers earlier, does not compensate for the limitation of the rights of claimants as set out in Article 19. Thanks to this provision, settlements can be viewed by infringers as a method of avoiding (or at least significantly limiting) follow-on damages claims. The opinion has to be supported that if this becomes the case, claimants would probably be denied final infringement decisions and some of the benefits of the New Directive will be undermined'11.

\section{Subject-matter dimension of antitrust liability}

\section{General rules for the scope of damages}

The Damages Directive confirms not only what the CJ used to say about the 'content' of damages (e.g. in Manfredi ${ }^{12}$ ), but what is also simply a basic rule of civil liability in a vast majority of EU Member States. Hence, the concept of 'harm' (including antitrust harm) covers: actual loss (damnum emergens), loss of profits (lucrum cessans) and - if appropriate - interests. The principle of full compensation is established in Article 3(2) of the Damages Directive. This

11 M. de Sousa e Alvim, 'The new EU Directive on antitrust damages - a giant step forward?' (2015) E.C.L.R. 36(6) 248.

12 Joined cases C-295/04 to C-298/04, Manfredi v. Lloyd AdriaticaAssicurazioniSpA et al. [2006] ECR I-06619. 
was certainly the only solution that could have been adopted in continental Europe, any other solutions would be too contradicting for domestic civil laws.

The many complaints expressed over difficulties in calculating damages in antitrust cases cannot be shared, albeit it is true that the assessment is not easy. It is fair to say however that assessing losses (actual or lost profits) caused by anticompetitive practices is not actually much more difficult than with respect to some other types of torts, either in economic/ commercial law, or other legal branches such as medical law for example. Is it really so much more difficult to calculate loss resulting from a price cartel than loss caused by the illegal use of trademarks or by the disclosure of trade secrets? These two examples come, for example, from the Polish Law on Unfair Competition ${ }^{13}$ (in force since 1993) which nobody dares to criticize as 'inapplicable' because of problems with assessing 'harm'.

Article 3(3) of the Damages Directive excludes the possibility of overcompensation 'whether by means of punitive, multiple or other types of damages'. However, this provision is not formulated in a very decisive manner and so it cannot be treated as an absolute ban on punitive or multiple damages. Punitive damages, for example, might very well be equal to, or even smaller than damages reflecting all three of the abovementioned elements required by the principle of full compensation. Considering problems caused by the recognition of judgments from foreign courts granting, for instance, punitive damages ${ }^{14}$, it would probably have been much better if the Directive directly prohibited multiple and punitive damages.

\section{Passing-on of overcharges}

Probably one of the most controversial issues in private antitrust enforcement is the possibility to defend against a damages claim by proving that the overcharges were passed-on to another (other) level(s) of trade ${ }^{15}$. Overcharges may be passed-on in both directions: downwards (to purchasers)

13 Act of 16 April 1993 on Combating Unfair Competition (consolidated text: Journal of Laws 2003 No. 153, item 1503 as amended).

14 See an order of the Polish Supreme Court of 11 October 2013, I CSK 697/12.

15 There is extensive literature on this issue e.g.: A.S. Gehring, 'The power of the purchaser: the effect of indirect purchaser damages suits on deterring antitrust violations' (2010) $5 \mathrm{New}$ York University Journal of Law and Liberty 208-246; F. Cengiz, 'Passing-On Defense and Indirect Purchaser Standing in Actions for Damages against the Violations of Competition Law: What Can EC Learn from US?' (2007) 21 ESRC Centre for Competition Policy and School of Law, University of East Anglia, CCP Working Paper; W.M. Landes, R. Posner, 'Should Indirect Purchasers Have Standing to Sue Under the Antitrust Laws? An Economic Analysis of the Rule of Illinois Brick' (1979) 46 University of Chicago Law Review 602 et seq.; J. Cirace, 'Price-Fixing, 
as well as upwards (to suppliers). Admitting the significance of passing-on of overcharges has varied consequences. First, it makes it possible to exclude, or at least limit, antitrust liability of infringers. Second, it prolongs the list of entities - ones located in a vertical order - which may be liable (and may be sued) for an antitrust harm. Third, the circle of potential claimants grows including both direct and indirect purchasers/suppliers, which did not necessarily have any (direct) relations with the infringer.

Despite all controversies concerning the passing-on of overcharges, reflected by attempts to overrule 'classical' judgments denying the passing-on defence in the US ${ }^{16}$ and expressed at various stages of the lawmaking process in the EU, the European lawmaker decided to introduce the passing-on defence into the Damages Directive (Article 12(1)). On the flip side, it also introduced the possibility to claim damages from undertakings other than those that, for instance, directly sold products covered by the infringement (Article 13). An infringer may get relief from antitrust civil liability if it is able to prove that it had passed-on the overcharges, entirely or partly, to its purchasers or suppliers (Article 13). Trying to prove the loss, an infringer may use either its own evidence or evidence 'already acquired in the proceedings or evidence held by other parties or third parties' (recital 39 of the Damages Directive's Preamble).

The Directive's provisions establishing rules for the disclosure of evidence will certainly be very helpful to infringers eager to use the passing-on defence. In addition, if the 'passing-on' decreases sales, a loss of profit is then considered to constitute 'harm' that should be fully compensated in accordance with general rules (Article 12(3)). The duties and the privileges of direct and indirect purchasers seem to in balance, due to the Directive indirect purchaser suits are not remain subsidiary ('taking place in the few cases when direct purchasers benefit from the cartel and are unwilling to commence litigation, ${ }^{17}$ ), although a subsidiary nature of indirect purchaser suits is suggested in literature as a possible solution to the 'passing-on standing matrix ${ }^{18}$.

Privity, and the Pass-On Problem in Antitrust Treble-Damages Suits: A Suggested Solution' (1977) 19(2) William \& Mary Law Review 171-202.

${ }^{16}$ Hanover Shoes Inc. v. Unites Shoe Machinery Corp., 392 U.S. 481 (1968); Illinois Brick Co. et al. v. Illinois et al., 431 U.S. 720 (1977). The most important attempt to change the so-called Illinois Brick doctrine (rules) was a report by the Antitrust Modernization Commission (2007). See: D. R. Karon, 'Your Honor, Tear Down that Illinois Brick Wall!: The National Movement Towards Indirect Purchaser Antitrust Standing and Consumer Justice' (2004) 30 William Mitchell Law Review 1351-402.

17 T. Dumbrovský, 'Passing-on-standing Matrix in Private Antitrust Enforcement: a Reconciliation of Economic and Justice Approaches' (2013) 30 EUI Working Papers MWP, p. 22.

18 Ibidem, p. 1-22. 
Accepting passed-on overcharges as a source of antitrust civil liability is linked to many problems and dangers. One of them is the probability of overcompensation - the EU lawmaker warns Member States against it in Article 12(2) of the Directive, but does not provide any specific tools or institutions that could help avoid such risk. Overcompensation is quite probable in light of Article 14(2) that establishes a sort of presumption regarding the proof of the passing-on of overcharges. The presumption may be eliminated by credibly demonstrating that a defendant did not, in fact, pass-on the overcharges to an indirect purchaser.

The possibility to make a damages claim against an undertaking, to which overcharges were passed-on, makes antitrust liability almost unlimited. This is so especially because the Directive does not set any limits regarding the number of levels of trade from which damages can be demanded. The situation of claimants seems to be pretty comfortable also in the context of their duties to prove the passing-on of overcharges and so it is probable that claimants will benefit from these provisions. But the very construction of the passing-on defence, as well as the way in which it was regulated, is quite sophisticated. The application of these new rules requires very deep knowledge of the market and of specific trade relations, as well as of competition law mechanism as such. It is fair to fear therefore - albeit being aware of the fact that the problem is considered here through the prism of Poland's underdeveloped private antitrust enforcement system ${ }^{19}$ - that the issue of 'passing-on' will prove too difficult for national courts to deal with ${ }^{20}$. Taking into account national perspectives, and barriers that exist in individual Member States to the development of private enforcement (obstacles that are mainly mental), it would have been better to not include passing-on as a source of antitrust liability in the Damages Directive and instead, to learn first how to enforce competition law before civil courts in a 'traditional' manner.

The regulation of private enforcement of competition law can take place in two stages: basic rules on private enforcement as a starting point first, followed by more advanced rules, including those on passing-on, a few years later. It is however completely clear that the European debate on private enforcement did not leave much space for such a solution. Indeed, the opinion

19 A. Jurkowska-Gomułka, 'Private Enforcement of Competition Law in Polish Courts: The Story of an (Almost) Lost Hope for Development' (2013) 6(8) YARS 107-128; M. Gac, 'Individuals and the Enforcement of Competition Law - Recent Development of the Private Enforcement Doctrine in Polish and European Antitrust Law' (2015) 8(11) YARS 53-82.

20 A similar opinion was expressed by E. Büyüksagis who writes: 'From the perspective of courts, direct purchasers and indirect purchasers, it is unfortunate that the new Directive did not prohibit the passing-on defence' - E. Büyüksagis, 'Standing and Passing-on in the New EU Directive on Antitrust Damages Actions' (2015) 87(1) Swiss Review of Business Law 24. 
has to be supported that the EU lawmaker acknowledges the rules on the passing-on defence as too complicated - this uncertainty about applying them is confirmed by Article 15 of the Damages Directive which 'grants national courts discretion to avoid instances of multiple liability, or no liability due to the rules expressed in Articles 12 to $14^{\prime 21}$.

\section{Umbrella pricing}

In recent years, the $\mathrm{CJ}$ delivered a few significant rulings referring to private antitrust enforcement including, importantly, the Kone judgment. It was confirmed therein that cartel members were liable also for harm caused by a price increase resulting from the cartel's activity (the so-called 'umbrella pricing'). The core problem in this case related to the fact that Austrian law and jurisprudence required - for non-contractual liability - an adequate causal link between the loss and the activity that caused it as well as the link of unlawfulness (paragraph 13 Kone). According to the adequate causal link criterion, a plaintiff may also be liable for indirect losses if these are results that he could have foreseen in abstracto, including accidental ones, but not for atypical consequences (paragraph 14 Kone). By contrast, Austrian caselaw used to see umbrella pricing as an extraordinary result of a cartel, so there was no possibility of obtaining compensation from cartel members for resulting losses. Neither the CJ nor, earlier, Advocate General Julianne Kokott approved the Austrian approach. The CJ referred to the full effectiveness of Article 101 TFEU which 'would be put at risk if the right of any individual to claim compensation for harm suffered were subjected by national law, categorically and regardless of the particular circumstances of the case, to the existence of a direct causal link while excluding that right because the individual concerned had no contractual links with a member of the cartel, but with an undertaking not party thereto, whose pricing policy, however, is a result of the cartel that contributed to the distortion of price formation mechanisms governing competitive markets' (paragraph 33 Kone).

Two findings must be criticised with respect to the Kone judgment. First, it has to be argued that liability of cartel members for harms resulting from umbrella pricing goes too far. This is so not only because such liability seems unlimited and impossible to estimate or calculate, but mainly because liability in such a dimension somehow loses its individual character (a typical feature of civil liability). As such, it turns into general liability for the performance of the entire market. It is especially difficult to accept the above approach considering

21 S. Peyer, 'Antitrust Damages Directive...', p. 45. 
the fact that an undertaking applying umbrella prices may certainly have not suffered any losses from it. In other words, liability for umbrella prices, which in fact translates into liability for the overall effects of a cartel, implements to some extent goals of public rather than private antitrust enforcement.

Worse yet, the CJ did not specify the detailed criteria for liability for umbrella pricing (in particular, it did not develop the concept of causation ${ }^{22}$ ). In addition, the CJ once again showed that the principle of effectiveness of EU law wins the battle on the scope of private enforcement, and that procedural autonomy of EU Member States is nothing but an illusion. This conclusion is alarming in a view of the fact that the Damages Directive leaves much to domestic legislation, or even just to the activities of national courts. 'Blank spaces' in the Directive are considered necessary limits for intervening in private law which is still - despite a strong influence of EU law - a sensitive area concerning a State's independence from external influences. Yet after the Kone case, it seems that the principle of effectiveness of EU law is actually able to eliminate all elements of Member States' freedom. If so, it would have been more rational to adopt a Damages Regulation instead of a Damages Directive.

\section{Final remarks}

The Damages Directive cannot be read separately from EU jurisprudence on private enforcement of competition law. First, because the Directive's content was partly based on EU judgment and second, because the CJ, the creator of the 'negative harmonization framework' 23 , is and will remain active in the interpretation of the rules and ideas supporting (or sometimes rather discouraging) private enforcement of Article 101 and 102 TFEU (and corresponding national rules).

A key issue in the rules and jurisprudence on private antitrust enforcement is to achieve and sustain a good balance between the private and public methods of enforcing the two prohibitions of competition restricting practices. A desired balance means that both enforcement models are able to achieve their key goals: repression and deterrence for public enforcement and compensation for private enforcement. The Damages Directive generally tries to reach such balance but there are some issues that spoil the effect. Rules and case law that

22 I. Lianos, 'Casual certainty and damages claims for infringement of competition law in Europe' (2015) 2 CLES Research Paper Series 4.

${ }^{23}$ L.F. Pace, 'The ECJ's judgment in Kone and private enforcement's "negative harmonization framework": Another Brick in the Wall' (Part 6) (2015) 2(1) Italian Antitrust Review. 
can endanger the desired balance can be found both in the purely procedural sphere as well as in material rules establishing the scope of antitrust civil liability. The paper focuses solely on the latter.

The hardest criticism should relate to Article 11(2) of the Damages Directive - the basis for a derogation of SMEs from the general rule of joint and several liability. Worst yet, this derogation does not even support public antitrust policy but covers other, not necessarily fully justified, public policy objectives. Other provisions of the Directive, those on the scope of antitrust civil liability and those that allow the modification of general rules for reasons of public policies (such as the derogation for immunity recipients), deserve complete approval as they maintain a balance between both methods of antitrust enforcement.

However, far more has been done to extend the scope of antitrust civil liability in order to strengthen private enforcement of competition law. The approval of 'passed-on' damages and liability for 'umbrella pricing' may become, for private antitrust enforcement, a typical example of throwing the baby out with the bath water. Very broad, almost unlimited, civil liability may be devastating for undertakings. Private enforcement might thus ultimately be effective $a$ rebours: instead of strengthening competition, private enforcement might kill it as a result of forcing individual undertakings out of business due to excessive damages.

\section{Literature}

Büyüksagis E., 'Standing and Passing-on in the New EU Directive on Antitrust Damages Actions' (2015) 87(1) Swiss Review of Business Law.

Cengiz F., 'Passing-On Defense and Indirect Purchaser Standing in Actions for Damages against the Violations of Competition Law: What Can EC Learn from US?' (2007) 21 ESRC Centre for Competition Policy and School of Law, University of East Anglia, CCP Working Paper.

Cirace J., 'Price-Fixing, Privity, and the Pass-On Problem in Antitrust Treble-Damages Suits: A Suggested Solution' (1977) 19(2) William \& Mary Law Review.

Davis S.J., Haltiwanger J., Schuh S., 'Small Business and Job Creation: Dissecting the Myth and Reassessing the Facts' (1993) 8(4) Small Business Economics.

de Sousa e Alvim M., 'The new EU Directive on antitrust damages - a giant step forward?' (2015) 36(6) E.C.L.R.

Gac M., 'Individuals and the Enforcement of Competition Law - Recent Development of the Private Enforcement Doctrine in Polish and European Antitrust Law' (2015) 8(11) YARS.

Gehring A.S., 'The power of the purchaser: the effect of indirect purchaser damages suits on deterring antitrust violations' (2010) New York University Journal of Law and Liberty 5. 
Dumbrovský T., 'Passing-on-standing Matrix in Private Antitrust Enforcement: a Reconciliation of Economic and Justice Approaches' (2013) 30 EUI Working Papers $M W P$.

Gruenwald R.K., 'Alternative Approaches in Evaluating the EU SME Policy: Answers to the Question of Impact and Legitimization' (2014) 2(2) Entrepreneurial Business and Economics Review.

Hirschberg D., The Job-Generation Controversy: The Economic Myth of Small Business, Routledge 2015.

Jurkowska A., 'Antitrust Private Enforcement - Case of Poland' (2008) 1(1) YARS.

Jurkowska-Gomułka A., 'Private Enforcement of Competition Law in Polish Courts: The Story of an (Almost) Lost Hope for Development' (2013) 6(8) YARS.

Karon D.R., 'Your Honor, Tear Down that Illinois Brick Wall!: The National Movement Towards Indirect Purchaser Antitrust Standing and Consumer Justice' (2004) 30 William Mitchell Law Review.

Landes W.M., Posner R., 'Should Indirect Purchasers Have Standing to Sue Under the Antitrust Laws? An Economic Analysis of the Rule of Illinois Brick' (1979) 46 University of Chicago Law Review.

Levine R., 'Should government and aid agencies subsidize small firms' [in:] L. Brainard (ed.), Transforming the Development Landscape: The Role of the Private Sector, Washington 2006.

Lianos I., 'Casual certainty and damages claims for infringement of competition law in Europe' (2015) 2 CLES Research Paper Series.

Pace L.F., 'The ECJ's judgment in Kone and private enforcement's "negative harmonization framework": Another Brick in the Wall' (Part 6) (2015) 2(1) Italian Antitrust Review.

Pais S.O., Piszcz A., 'Package on Actions for Damages Based on Breaches of EU Competition Rules: Can One Size Fit All?' (2014) 7(10) YARS.

Parker R., 'The Myth of the Entrepreneurial Economy' (2001) 15(2) Work, Employment and Society.

Peyer S., 'Antitrust Damages Directive - much ado about nothing?' [in:] M. Marquis, R. Cisotta (eds.), Litigation and arbitration in EU competition law, Edward Elgar Publishing 2015.

Podrecki P., 'Civil Law Actions in the Context of Competition Restricting Practices under Polish Law' (2009) 2(2) YARS.

Stefanicki R., Prywatnoprawne środki dochodzenia roszczeń z tytułu naruszenia regut konkurencji [Private measures for fullfiling damages resultig from violations of competition rules], Warszawa 2014. 